ternary alloys together with the quaternary aluminium-copper-magnesium-silicon and aluminiummagnesium-silicon-manganese alloys; in one case, aluminium - zinc-magnesium - copper - manganese, a start has been made on a quinary series.

The work has most clearly justified the time and money expended on it, and this publication provides a first-rate summary of the results which have been obtained.

F. C. Thompson

\section{A RARE CRYPTOMERIA}

$\mathrm{Y}$

AKU-SHIMA, an island about thirty-seven miles off Kyushu, Japan, and covering approximately 190 square miles, is famed for the forests that cover its steep mountain-sides and for its abundant wildlife, especially deer and monkeys. The really unique and outstanding feature of the island, however, is the Cryptomeria japonica or 'Yaku-sugi' trees that are found there. These can be compared with the world's most spectacular trees, both because of their size-they grow to $16 \frac{1}{2} \mathrm{ft}$. in diameter and $117 \mathrm{ft}$. high -and their age, which is calculated to bo between 1,000 and 3,000 years old. Their classification in systematic botany is not clear, although they are believed to be the ancestors of the Japanese species of Cryptomeria, in spite of differing from them both morphologically and ecologically. At one time there seoms to have been a mysterious gap in the species' ecology, due either to its requirements or the conditions it was subjected to, as no trees are to be found between four hundred and eight hundred years old; they are all either older or younger. The Yaku-Shima virgin forests are of great interest, for the Yalku-sugi trees grow there along with firs, hemlock and Yamagurumas (Trochodendron aralioides, Sieb. et Zuce), and fill the island's valleys with tall trees decorated with intertwining epiphytic and parasitic plants.

At present, negotiations are going on between the Forestry Agency of the Ministry of Agriculture and Forestry and the National Park Division of the Ministry of Welfare to see whether the area should be designated as a national park. It would be a tragedy if the island's beauty were not perpetuated for future generations, and the International Union for the Protection of Nature has offered all possible help to its member, the National Parks Association of Japan, which in its turn is supporting the National Park Division's project (Bull. Inter. Union Protect. Nature, 4, Nos. 5 and 6; December 1955).

\section{WEATHER AND THE LAND}

$\mathrm{D}$

URING the early years of his period of office the late Sir Nelson Johnson, director of the meteorological Office during 1938-53, realized that much greater assistance could and should be given by the Office to the economic life of Great Britain. One of his major decisions in this respect was the establishment in 1947 of the Agricultural Meteorological Section of the Climatology Branch, the Section becoming in 1948 the Agricultural Branch of the Office under the assistant director for climatology. Since then the Branch has developed its activities very widely. Besides the Branch office at the headquarters of the Meteorological Office, there are now meteorological advisers at the offices in Bristol and
Cambridge of the National Advisory Service for Agriculture, and a meteorologist has recently been posted to the Meteorological Office, Edinburgh, for similar duties in Scotland.

A pamphlet written by the staff of the Branch* explains to the farmer the 'why and how' of his meteorological problems, how meteorologists can help to solve the problems, and how best to use the forecasts prepared at the Central Forecast Office and broadcast by the B.B.C.

The first chapter describes the general climate of the British Isles with special reference to plant growth, and the second gives the local variations in climate associated with altitude, aspect, and the nature of the soil and its covering. The third chapter explains the meteorological aspects of methods available for using solar radiation more efficiently by means of glasshouses and cloches, and methods such as shelterbelts and irrigation, of mitigating unfavourable meteorological effects. After this is a chapter describing the structure of depressions and the use of cloud forms and other portents of weather in interpreting the broadcast forecasts and applying them to local conditions. Finally, the fifth chapter gives the times of and areas used in the broadcast forecasts, lists the local meteorological offices from which forecasts can be obtained by telephone and the various special forecast services such as spell warnings which are available, defines terms used in weather forecasts, and states how the farmer can obtain advice (from headquarters, or from the meteorological offices attached to the National Advisory Service or to the Edinburgh Meteorological Office) on making the best use of his land.

The pamphlet gives a general compendium of meteorological knowledge as applied to agriculture in all its aspects and is of very great value to all agriculturists, while the parts on the use of the broadcast forecasts would be of much value to those whose business or pleasure is affected by the weather. Chapter 4 could well be used in schools for teaching the use of weather forecasts.

* Bulletin No. 165 of the Ministry of Agriculture. Fisheries and Food: Weather and the Land. Pp. iv $+35+4$ plates. (London: H.M.S.O., 1955.) 3s. net.

\section{EMPLOYMENT STATISTICS FOR RECENT BRITISH GRADUATES}

A

RECENT broadsheet on "Graduates' Jobs", issued by Political and Economic Planning (No. 387), summarizes the results of an inquiry into the careers of 3,961 men who graduated in Great Britain in 1950. Returns were received from some 30 per cent of these, and it is unlikely that there is any main source of bias in the sample; more than half graduated in arts, more than a quarter in science, and less than one-fifth in technology. Many were older than the normal run of graduates, and most had seen war service or had done national service before going to a university. More than half had married by October 1954, and 20 per cent had married in the year they graduated or earlier.

Much the largest entries were into industry and teaching (both 23.4 per cent), mathematics and science teaching claiming 6.7 per cent, while 33 per cent of arts graduates became teachers as compared with 19.9 per cent of science graduates. The Civil Service took 8.6 per cent, 5.5 per cent (or 15.7 per 
cent of the science graduates and 3.9 per cent of those in technology) going into the Scientific Civil Service; 7.5 per cent went into commerce, 4.2 per cent into the universities, $4 \cdot 1$ per cent took up law, and 3.6 per cent went into local government service, including 8.3 per cent of the technologists. Of the technologists, 45.4 per cent went into manufacturing industry, $8 \cdot 8$ per cont into building, contracting and civil engineering, $6 \cdot 5$ per cent became consultant engineers and $6 \cdot 1$ per cent entered public utilities.

Industry claimed the highest proportion $(23.7$ per cent) of first-class honours graduates as well as second-class honours men (20.8 per cent) and $26 \cdot 4$ per cent of others, but over the past four years lost about 10 per cent of its entrants; the Scientific Civil Service claimed $11 \cdot 0$ per cent of first-class honours men and $\mathbf{5 . 5}$ per cent of those with secondclass honours. Since 1950 it has lost 7 per cent of its intake. The universities, however, which claimed 17.8 per cent of first-class honours men, increased their share of graduates by nearly 4 per cent, whereas school teaching, which by contrast only attracted 2.8 per cent of first-class honours men in mathematics and science, $4 \cdot 6$ per cent of second-class honours men and 10.3 per cent of others (the corresponding figures for arts men being $6 \cdot 5,20 \cdot 6$ and $15 \cdot 2)$ lost 7 per cent of its original entrants.

Commerce lost 25 per cent of the graduates who started in it; but in general there was a high degree of stability in occupation. Figures for the research associations, which took 2.9 per cent of the science graduates (as compared with $6 \cdot 0$ per cent for the universities) or 1.4 per cent of first-class and $1 \cdot 7$ per cent of second-class honours men, do not suggest that they absorb as yet any considerable proportion of the country's scientific man-power, but rather that their influence may be out of proportion to the numbers, like that of the universities, owing to the high quality.

\section{ENGINEERING RESEARCH IN THE IMPERIAL COLLEGE, LONDON}

The

HE report on research work in the City and Guilds College, 1952-55*, which represents engineering within the Imperial College of Science and Technology, London, where the number of engineering students now exceeds a thousand, appears appropriately when the expansion of the College is being widely discussed in relation to the need for engineers in Britain. Intended for the non-specialist and arranged in six sections, the report gives a readable and illustrated account of the many-sided contribution to national welfare and industrial advance which is already coming from the Departmonts of Aeronautics, Chemical, Civil, Electrical and Mechanical Engineering and Mathematics. In supersonics, while much effort has gone to the design of the new supersonic wind tunnel for the Roderic Hill Building, some theoretical work has been done on the pressures and forces acting on aircraft fuselages as they move through the air at supersonic speeds; detailed measurements are being made in a $5 \mathrm{ft} . \times 1 \mathrm{ft}$. wind tunnel on a jet ejected normal to a stream to determine how and why the jet turns along wind. General methods of analysis of aircraft structures have been

- Imperial College of Science and Technology (University of London). Report on research work in the City and Guilds College, 1952-55. Pp. i $i+61$. (London: Imperial College of Science and Technology, 1955.) developed, including the effects of non-linear elastic behaviour of materials and initial strains which arise with non-uniform heating of a structure. A systematic programme of tests over the past two years on riveted and redux-bonded joints indicates that the glued joints have better fatigue properties than their riveted equivalents, and that alloys of high static strength currently used in aircraft structures may be inferior under repeated loadings, particularly in regions of high-stress concentrations, such as joints, to the lower-strength alloys.

In chemical engineering, in connexion with the design of plant for purifying and liquefying natural gas on a large scale, the physical properties of the gas mixtures present are being further investigated, and an experimental plant has been erected for studying the distillation of liquid air. Problems of mass-transfer in solid-gas, solid-liquid, gas-liquid, and liquid-liquid systems, the drying characteristics of solids, the sedimentation of concentrated suspensions of particles in a liquid, fluidization of particles by means of an upward current of liquid, and transport by means of a gas or liquid are also being investigated, and an apparatus has been set up for studying both the sublimation of pure solids and the technical process of freeze-drying. The growth of an organic crystal from the melt has been investigated by a method in which the growth of individual faces is measured directly with a travelling microscope. The compressibilities of mixtures of steam and carbon dioxide have been measured up to 100 atmospheres and $650^{\circ} \mathrm{C}$. In the high-speed fluid kineties laboratory, the high-pressure supersonic flow through nozzles and the design of such nozzles for hot and cold gases are being studied, as well as the formation and disintegration of jets and sheets and the design of nozzles for atomization. Methods for concentrating low-grade iron ores have been examined, and an experimental technique has been designed for subjecting typical blast-furnace charges to the conditions they would encounter in descending the furnace. Other researches have been concerned with the basic chemical physics of gases and vapours, the melting of crystals containing organic molecules, mechanical wear and lubrication, the abrasion of copper and iron surfaces, flame spectroscopy and the accurate and detailed analysis of the peroxides, aldehydes, ketones, olefins and other intermediate products in the oxidation of hydrocarbons; and a fruitful study has been made of engine crank-case explosions.

In civil engineering, in connexion with the design of a large arch dam to be constructed at Dokan, Iraq, on a tributary of the Tigris, the elastic equations governing the stress distribution have for the first time been solved numerically, and the work assisted and confirmed by experimental methods using a material which has only recently become available. Work on thin-walled rectangular box girders conducted for the British Shipbuilding Research Association confirmed that introduction of expansion joints is a practice to be avoided. The Department has also fostered the application of simplified models to the analysis of building frames. Much work has been done on the fundamental strength and deformation characteristics of both reinforced and pre-stressed concrete framework members. Experiments on curved channels have vielded far-reaching results, and definite progress has been made in studying the movement of sediment along a river bed. Of particular interest are the work on the action of wind 